DOI: 10.32844/2222-5374-2020-104-2.30

УДК: 347.73

Нікітін В. В., кандидат юридичних наук, докторант

Науково-дослідного інституту публічного права

\title{
ДО ХАРАКТЕРИСТИКИ ЗМІСТУ ПРИНЦИПУ АДЕКВАТНОСТІ В МІЖНАРОДНИХ УГОДАХ ПРО УНИКНЕННЯ ПОДВІЙНОГО ОПОДАТКУВАННЯ
}

Актуальність статті полягає в тому, що міжнародна співпраця щодо податкових питань між владами різних країн дозволяє розв'язувати спірні питання, що стосуються подвійного оподаткування й застосування податкових законів, а також здійснювати обмін інформацією з метою боротьби з ухилянням від сплати податків, провадити діяльність по боротьбі з міжнародною злочинністю у цій царині. Співробітнищтво на міжнародному рівні у формі укладання міжнародних податкових угод сприяє встановленню гарантій щодо незастосування дискримінаційного оподаткування стосовно громадян і резидентів Договірних держав. Названі зобов'язання є надзвичайно важливою умовою, що забезпечує виконання різних економічних угод і домовленостей, спрямованих на забезпечення свободи торгівлі, оскільки вони стосуються всіх податків, а не тільки охоплюваних тією чи іншою угодою. Разом із тим, щоб міжнародна співпраця була більш ефективною, вона має будуватись на відповідних засадах, серед яких важливе місце належить принщипу адекватності. У статті, спираючись на аналіз наукових поглядів вчених та норм чинного вітчизняного і зарубіжного законодавства, надано характеристику принципу адекватності в міжнародних угодах про уникнення подвійного оподаткування. Обгрунтована важливість та доцільність закріплення на законодавчому рівні принципу адекватності, що дозволить більш комплексно підійти до розв'язання проблем подвійного оподаткування. Зроблено висновок, що для платника це надзвичайно важлива норма, адже він отримує практичний засіб захисту своїх інтересів в іншій державі. У цьому полягає перевага порівняно із ситуацією, коли податкової угоди немає: по-перше, є можливість подати скаргу на дії податкових органів іншої країни органам своєї країни, резидентом або громадянином якої він є; по-друге, податкові органи його країни можуть вступити у прямі перемовини чи контакти з органами іншої країни, щоб розв'язати його питання. Якщо бракує угоди, таких можливостей не існує, і платник податку може розраховувати лише на процедуру оскарження, що передбачена в країні, де, на його думку, він зазнав податкової дискримінації щодо оподаткування його доходу.

Ключові слова: принцип адекватності, міжнародні угоди, подвійне оподаткування, міжнародне законодавство.

Актуальність теми. Міжнародна співпраця щодо податкових питань між владами різних країн дозволяє розв'язувати спірні питання, що сто- 
суються подвійного оподаткування й застосування податкових законів, а також здійснювати обмін інформацією з метою боротьби з ухилянням від сплати податків, провадити діяльність по боротьбі з міжнародною злочинністю у цій царині. Співробітництво на міжнародному рівні у формі укладання міжнародних податкових угод сприяє встановленню гарантій щодо незастосування дискримінаційного оподаткування стосовно громадян i резидентів Договірних держав. Названі зобов'язання $\epsilon$ надзвичайно важливою умовою, що забезпечує виконання різних економічних угод і домовленостей, спрямованих на забезпечення свободи торгівлі, оскільки вони стосуються всіх податків, а не тільки охоплюваних тією чи іншою угодою. Разом із тим, щоб міжнародна співпраця була більш ефективною, вона має будуватись на відповідних засадах, серед яких важливе місце належить принципу адекватності.

Стан дослідження. Варто відзначити, що окремі проблемні питання, присвячені принципам уникнення подвійного оподаткування у своїх наукових працях розглядали: І.В. Педь, О.Я. Бозуленко, А.С. Захаров, С.Ф. Сутирін, A.I. Погорлецький, С.Г. Пепеляєва, Г.П. Толстоп'ятенко та багато інших. Втім, незважаючи на чималу кількість наукових здобутків, в юридичній літературі відсутні комплексні дослідження, присвячені характеристиці змісту принципу адекватності в міжнародних угодах про уникнення подвійного оподаткування.

Саме тому метою статті є: надати характеристику змісту принципу адекватності в міжнародних угодах про уникнення подвійного оподаткування.

Виклад основного матеріалу. Початковим етапом установлення змісту принципу адекватності в угодах про уникнення подвійного оподаткування є сфера поширення податкової юрисдикції кожної з Договірних держав, що визначається статтями цих угод. Ця сфера охоплює: осіб, до яких застосовуються норми договору (принцип резидентства); податки, на які поширюються положення конкретних договорів; територію, на якій чи щодо якої діє договір (принцип територіальності). Згадані статті мають вирішальне значення при адекватному впорядкуванні податкових відносин, оскільки вони окреслюють коло суб'єктів податкових правовідносин і об'єктів оподаткування в межах більш ніж однієї податкової юрисдикції.

Угоди про уникнення подвійного оподаткування, як свідчать їх назви, стосуються на податки з доходів і майна. Проте конкретні види податків, на які поширюються ці угоди, завжди деталізуються. Статті, що встановлюють види таких податків, значною мірою різняться в угодах, укладених Україною (СРСР) з іншими країнами. Це пояснюється специфікою системи оподаткування держав, з якими укладалися угоди, прагненням договірних сторін розширити чи звузити сферу дії угод, і податковими змінами, що відбувалися в договірних державах у різні періоди.

Угоди завжди поширюються на загальнодержавні (центральні, федеральні, конфедеральні) податки на доходи й майно юридичних і фізичних осіб. Відмінності між угодами, укладеними з різними країнами, часто полягають у поширенні (чи непоширенні) їх дії на оподаткування фондів заробітної плати, акцизи, на податки, встановлені стосовно доходів від інвестицій приватних осіб та організацій, на оподаткування приросту капіталу, 
внесків у фонди соціального страхування й на низку інших видів оподаткування. Незважаючи на те, що практично всі угоди про усунення подвійного оподаткування містять положення про поширення їх дії на нові запроваджені податки, для практичного застосування угоди, що стосується тих чи інших нових податків, завжди потрібно мати письмове підтвердження, що той чи інший податок чи збір включено до числа тих податків, на які поширюється дія конкретної угоди.

У договорах (угодах) України міститься спеціальна стаття (як правило, це ст. 2) під назвою “Податки, на які поширюється Конвенція». У ній зазначається, що Конвенція застосовується до податків на доходи й майно, що стягуються від імені Договірної держави, її територіально-адміністративного підрозділу, або місцевої влади незалежно від способу їх стягнення. За загальним правилом податкові конвенції поширюються в Україні на податок на прибуток підприємств і на прибутковий податок із фізичних осіб.

В угодах наводиться загальне визначення, що податками на дохід і на майно вважаються всі податки, що справляються від загальної суми доходу й вартості майна або з елементів доходу, включаючи податки на доходи від відчужування майна й податки на загальну суму заробітної плати і платні, сплачуваних підприємством [1]. Як бачимо, при визначенні податків в угодах про уникнення подвійного оподаткування основним завданням $\epsilon$ прагнення держав до максимально тотожного впорядкування податкових відносин, тобто втілення принципу адекватності правового регулювання податкових інтересів держав на міжнародному рівні.

Територіальне поширення податкових угод пояснюється через тлумачення 2-х основних категорій - “Договірна держава" [1] й “Договірна держава в географічному розумінні" [2], які містяться у статті “Загальні визначення". При трактуванні поняття “Договірна держава" наводиться конкретна офіційна назва Договірної держави (приміром "Україна", "Узбекистан"). Ця назва використовується при тлумаченні другого поняття - “Договірна держава в географічному розумінні" ("наприклад Україна в географічному розумінні означає...”).

Конструкція “Договірна держава в географічному розумінні”, стосовно України, як правило, означає: термін "Україна" при використанні його в географічному значенні розуміється як територія України, її континентальний шельф і виключна (морська) економічна зона, а також будь-яка інша територія за межами територіальних вод України, яка за міжнародним правом визначається або в подальшому може бути визначена, як територія, в межах якої можуть здійснюватися права України стосовно морського дна, надр та їх природних ресурсів. Отже, розглядувана конструкція для зарубіжних Договірних держав означає територію кожної Договірної держави, включаючи їі територіальне море, виключну (морську) економічну зону й райони континентального шельфу, що простягаються за межі її територіального моря, стосовно яких згідно з нормами міжнародного права вона здійснює суверенні права з метою розвідки й експлуатації природних ресурсів цих районів.

В окремих договорах (угодах) це положення може бути доповнено чи змінено з метою забезпечення адекватної правової регламентації податкових відносин. У багатьох правочинах до наведеного визначення додано та- 
кож поняття “повітряний простір над усіма видами території” [3], і в угоді з Фінляндією - поняття “прилегла акваторія територіальних вод” [4], але не позначає виключну (морську) економічну зону й райони континентального шельфу. В угодах держав, які не мають виходу до моря чи мають такий вихід, але їм належать лише внутрішні територіальні води, не містяться положення про територіальне море, виключну (морську) економічну зону й райони континентального шельфу, що простягаються за межі територіального моря, а йдеться лише про внутрішні води [3; 5]. Правильне визначення того, входить чи не входить та чи інша залежна територія, острів, частки континентального шельфу до тієї території Договірної держави, на яку поширюється угода, має значення як для іноземних осіб, які здійснюють економічну діяльність на території країни перебування, так і для національних фірм, що проводять таку діяльність за кордоном. Зазначене є однією з умов забезпечення принципу адекватності правового регламентування податкових відносин на міжнародному рівні. Для практичного застосування угоди про уникнення подвійного оподаткування інколи необхідно одержати офіційне підтвердження компетентних органів того факту, що на цю територію поширюється дія цієї угоди.

Наступним етапом розкриття змісту принципу адекватності в міжнародних угодах про уникнення подвійного оподаткування $\epsilon$ визначення презумпції ідентичності відповідних національних податкових режимів щодо відповідних об’єктів і суб’єктів оподаткування. Для цього до них включено статті, що окреслюють межі юрисдикції кожної країни по обкладанню податком конкретні види доходів і капіталів (майна). Умовно згадані статті можна умовно поділити на 3 групи. Це статті: (a) що стосуються доходів від активної діяльності суб'єкта, пов'язаної з присутністю на території іншої держави; (б) що регулюють режим обкладання податком так званих пасивних доходів, і (в) про обкладання податком капіталів (майна). Крім того, сюди ж включено статті, що містять тлумачення деяких термінів, застосовуваних в угоді [6, с. 123]. Ця частина змісту принципу рівності в досліджуваних міжнародних угодах виражається у встановленні різних податкових режимів з метою запобігання подвійному оподаткуванню доходів і капіталів.

Об'єктами оподаткування нерезидента є: загальний місячний оподатковуваний дохід із джерелом його походження з України, загальний річний оподатковуваний дохід із джерелом його походження з України, доходи із джерелом їх походження з України, які підлягають кінцевому оподаткуванню при їх виплаті. Отже, для нерезидентів України об'єктом оподаткування $€$ доходи із джерелом їх походження з України, а для нерезидентів - доходи, одержані із джерел в Україні, а також іноземні доходи. Особи, які сплачують податки лише за доходами із джерел у Договірній державі, вважаються нерезидентами цієї держави. Вони користуються перевагами міжнародного договору, якщо $є$ резидентами другої країни - учасниці такого договору.

Якщо конфлікт виникає між країною - резиденцією доходу фізичної особи і країною - джерелом її доходу, застосовуються положення угод, які можна поділити на 3 великі групи. Зауважимо, що це положення не стосується пасивних доходів. Першу групу складають доходи, отримані від незалежної особистої діяльності, тобто від надання професійних послуг 
незалежної наукової, літературної, артистичної, викладацької чи іншої діяльності [4]. Друга група охоплює доходи, одержані від роботи за наймом; це заробітна плата та інші подібні типи винагород [7]. Третю групу становлять специфічні види доходів, тобто доходи певних категорій осіб, для яких такими міжнародними договорами встановлено особливі норми уникнення або зменшення подвійного оподаткування. До третьої групи включаються (а) гонорари директорів; (б) доходи (включаючи пенсії), що виплачуються з державних фондів або фондів адміністративно-територіальних утворювань; (в) пенсії, виплачувані з інших джерел; (г) доходи працівників сфери мистецтва і спортсменів; (д) винагороди, стипендії, а інші платежі, отримувані викладачами, вченими, студентами і практикантами, та ін. [2].

Що стосується оподаткування юридичних осіб, у цьому плані загальноприйнятим у міжнародних податкових відносинах $є$ принцип, що полягає в наступному: поки компанія чи інша особа не оформила своєї присутності на території іншої країни, її не можна розглядати як таку, що потрапляє під повну податкову юрисдикцію цієї країни (відповідно до концепцій “постійного представництва”, “ефективного зв'язку” тощо). Із цього однак можна зробити 2 різні висновки: (1) вся діяльність указаної особи в цій країні зводиться до її постійного представництва і для податкових цілей має шумуватись у виді їі доходів; (2) до діяльності постійного представництва можна віднести лише безпосередні доходи цієї особи. До речі, другий висновок підтримує й Модель ОЕСР. Більшість держав у своїх податкових угодах додержуються другої позиції, обмежуючи цим застосування норм свого внутрішнього права [8].

У договорах України про уникнення подвійного оподаткування міститься таке тлумачення: поняття “постійне представництво" означає постійне місце діяльності, через яке повністю або частково здійснюється підприємницька діяльність підприємства [9]. Утім, це положення не можна вважати повним визначенням конструкції “постійне представництво для цілей оподаткування” з 2-х причин: по-перше, незрозуміло, що розуміється під поняттям "постійне місцем діяльності"; по-друге, в ньому не визначені ті види діяльності, які надають постійному місцю діяльності характеру постійного представництва для цілей оподаткування. У наступних положеннях статті “Постійне представництво” перелічені ті об'єкти, які можуть розглядатися як постійне місце діяльності, й указуються ті види діяльності, здійснення яких не призводить до створення постійного представництва для цілей оподаткування.

Усунення подвійного оподаткування дивідендів, відсотків і роялті гарантується в результаті дій за взаємною згодою країн-партнерів. Існує дуже мало угод, у яких би країна-джерело повністю відмовлялась би від свого права оподатковувати ці доходи. Бажаний результат забезпечується в такий спосіб, що країна-джерело доходу зменшує ставку податку із джерела, а країна резидентства одержувача доходу враховує отриману суму податку (у формі іноземного податкового кредиту чи інакше) при визначенні податкових зобов'язань свого резидента. Проте, як правило, в доволі рідкісних випадках країни-партнери за податковими угодами домовляються про повну відміну податків із джерела. 
Закріплюючи презумпцію ідентичності тих чи інших національних податкових режимів щодо відповідних суб'єктів та об'єктів оподаткування, міжнародні угоди про уникнення подвійного оподаткування безпосередньо визначають зміст принципу адекватності, забезпечуючи тим самим досягнення компромісу податкових інтересів держав на міжнародному рівні.

Ще одним етапом визначення змісту принципу адекватності в міжнародних податкових угодах $\epsilon$ встановлення засад співробітництва держав з приводу забезпечення адекватності правового регулювання запобігання міжнародному подвійному оподаткуванню. На цьому етапі визначаються порядок відносин і співпраці між компетентними органами з виконання укладених угод, які містять дуже важливу статтю про узгодженість між сторонами методу уникнення подвійного оподаткування і статті про набуття і припинення чинності угоди. Для непередбачених ситуацій згідно з угодою за взаємною домовленістю між компетентними органами, існує спеціальний порядок, вирішення й цього питання, який поширюється не лише на випадки подвійного оподаткування, а й на будь-які інші випадки оподаткування, що мали місце, в розбіжність з укладеною угодою. Цей порядок є своєрідним останнім пунктом реалізації у всьому комплексі передбачених угодою засобів з усунення цього виду оподаткування. Статті “Процедура взаємного узгодження" й “Недискримінація" (мається на увазі недопущення податкової дискримінації) для платника податків $\epsilon$ найважливішими статтями угоди, оскільки забезпечують йому міжнародний захист від повторного чи надмірного оподаткування в іншій країні $[10 ; 11 ; 3]$. Цього права платник повністю позбавлений, якщо такої податкової угоди немає, оскільки він не є суб'єктом міжнародного права й може отримати міжнародний захист лише через звернення до компетентних органів держави, які вправі розв'язати проблеми, що виникли.

Висновки. Таким чином, процедура взаємного узгодження передбачає пред'явлення претензій платників податків до компетентних органів, якими за умовами угоди виступають міністерство фінансів країн, що домовляються. Для платника це надзвичайно важлива норма, адже він отримує практичний засіб захисту своїх інтересів в іншій державі. У цьому полягає перевага порівняно із ситуацією, коли податкової угоди немає: по-перше, $\epsilon$ можливість подати скаргу на дії податкових органів іншої країни органам своєї країни, резидентом або громадянином якої він є; по-друге, податкові органи його країни можуть вступити у прямі перемовини чи контакти 3 органами іншої країни, щоб розв'язати його питання. Якщо бракує угоди, таких можливостей не існує, і платник податку може розраховувати лише на процедуру оскарження, що передбачена в країні, де, на його думку, він зазнав податкової дискримінації щодо оподаткування його доходу. Крім того, ця особа не матиме ані права, ані можливості звернутися за допомогою до органів своєї країни. Податкові органи держав, що домовляються, можуть прямо контактувати між собою, з метою досягнення згоди з питань, що порушених платниками податків, влаштовувати усний обмін думками щодо існуючих проблем, створювати спільні комісії з представників компетентних органів обох держав.

Рекомендується, щоб ця стаття щодо взаємоузгодження була доповнена положенням, яке дало б змогу компетентним органам одержува- 
ти й надавати консультації з питань усунення подвійного оподаткування, які не передбачені конкретними конвенціями. Цей заключний етап визначення змісту принципу адекватності правового регулювання запобігання міжнародному подвійному оподаткування, закріплюючись у міжнародних податкових угодах, дозволяє повністю врегулювати проблему такого оподаткування й за особливих непередбачуваних обставин. Зазначене ще раз підтверджує об'єктивність існування цього принципу і втілення його в нормах міжнародних податкових угод.

\section{СПИСОК ВИКОРИСТАНИХ ДЖЕРЕЛ}

1. Угода між Урядом України і Урядом Республіки Вірменія про уникнення подвійного оподаткування та попередження ухилень стосовно податків на доходи і майно : від 14.05.1996 р. Офіційний вісник України. 2008. № 10. Ст. 259.

2. Угода між Урядом України і Урядом Китайської Народної Республіки про уникнення подвійного оподаткування та попередження податкових ухилень стосовно податків на доходи і майно : від 04.12.1995 р. Офіційний вісник України. 2008. № 7. Ст. 186.

3. Конвенція між Урядом України і Урядом Республіки Молдова про уникнення подвійного оподаткування доходів і майна та попередження податкових ухилень : від 29.08.1995 р. Офіційний вісник України. 2007. № 95. Ст. 3490.

4. Конвенція між Урядом України і Урядом Республіки Фінляндія про уникнення подвійного оподаткування та попередження податкових ухилень стосовно податків на доходи і майно : від 14.10.1994 р. Офіційний вісник України. 2010. № 25. Ст. 992.

5. Конвенція між Урядом України і Урядом Республіки Польща про уникнення подвійного оподаткування доходів і майна та попередження податкових ухилень : від 12.01.1993 р. Офіційний вісник України. 2006. № 17. Ст. 1315.

6. Петраш І. Ю. Цілі, завдання та види міжнародних угод України про уникнення подвійного оподаткування. Актуальні проблеми міжнародних відносин. Київ, 2000. Вип. 22, ч. 1. С. 129-137.

7. Угода між Україною і Федеративною Республікою Німеччина про уникнення подвійного оподаткування стосовно податків на доход і майно : від 03.07.1995 р. Офіційний вісник України. 2008. № 14. Ст. 348.

8. Explanation of Proposed Income Tax Treaty and Proposed Protocol Between the United States and Ukraine: Scheduled for a Hearing Before the Committee on Foreign Relations United States Senate on May 25, 1995. Washington, D. C.: U. S. Government Printing Office, 1995. 25 p. URL: https://www.jct.gov/ publications/1995/jcs-11-95/.

9. Конвенція між Урядом України і Урядом Сполученого Королівства Великобританії і Північної Ірландії про усунення подвійного оподаткування та запобігання податковим ухиленням стосовно податків на доходи і на приріст вартості майна : від 10.02.1993 р. Офіційний вісник України. 2005. № 29. Ст. 1761.

10. Конвенція між Урядом України і Урядом Республіки Македонія про уникнення подвійного оподаткування та попередження податкових ухи- 
лень стосовно податків на доходи і на капітал : від 02.03.1998 р. Офіційний вісник України. 2010. № 25. Ст. 995.

11. Конвенція між Урядом України і Урядом Королівства Данії про уникнення подвійного оподаткування та попередження податкових ухилень стосовно податків на доходи і майно : від 05.03.1996 р. Обіційний вісник України. 2008. № 7. Ст. 189.

\section{Nikitin}

\section{TO CHARACTERIZE THE CONTENT OF THE PRINCIPLE OF ADEQUACY IN INTERNATIONAL AGREEMENTS ON AVOIDANCE OF DOUBLE TAXATION}

The relevance of the article is that international cooperation on tax issues between the authorities of different countries allows to resolve disputes concerning double taxation and application of tax laws, as well as to exchange information to combat tax evasion, to conduct activities to combat with international crime in this area. Cooperation at the international level in the form of the conclusion of international tax treaties contributes to the establishment of guarantees of non-application of discriminatory taxation in respect of nationals and residents of the Contracting States. These obligations are an extremely important condition that ensures the implementation of various economic agreements and arrangements aimed at ensuring freedom of trade, as they apply to all taxes, not just covered by a particular agreement. However, in order for international cooperation to be more effective, it must be built on appropriate principles, among which the principle of adequacy is important. The article, based on the analysis of scientific views of scientists and the norms of current domestic and foreign legislation, provides a description of the principle of adequacy in international agreements on the avoidance of double taxation. The importance and expediency of enshrining at the legislative level the principle of adequacy, which will allow a more comprehensive approach to solving the problems of double taxation. It is concluded that this is an extremely important rule for the payer, because he receives a practical means of protecting his interests in another state. This is an advantage over a situation where there is no tax agreement: first, it is possible to file a complaint against the actions of the tax authorities of another country to the authorities of his country, a resident or citizen of which he is; second, the tax authorities of his country may enter into direct negotiations or contacts with the authorities of another country to resolve his issues. If there is no agreement, such opportunities do not exist, and the taxpayer can only rely on the appeal procedure provided for in the country where, in his opinion, he has been taxed in terms of taxation of his income.

Keywords: adequacy principle, international agreements, double taxation, international legislation. 